\title{
Penerapan Model Pembelajaran Kooperatif Tipe Jigsaw dalam Pembelajaran Fisika untuk Meningkatkan Aktivitas dan Prestasi Belajar Siswa
}

\author{
Sri Endang* \\ IKIP Mataram, Mataram, Indonesia \\ *Coresponding Author : sri.endang02@gmail.com \\ Dikirim: 17-07-2021 ; Direvisi: 01-08-2021 ; Diterima: 05-08-2021
}

\begin{abstract}
Abstrak: Penelitian ini bertujuan untuk mengetahui penerapan model pembelajaran kooperatif tipe jigsaw untuk meningkatkan aktivitas dan prestasi belajar siswa pada kelas VIIA semester I pada pokok bahasan Gerak Lurus SMP Muhammadiyah Mataram tahun pelajaran 2020/2021. Jenis penelitian yang digunakan adalah penelitian tindakan kelas, yang terdiri dari tiga siklus terdiri dari perencanaan, pelaksaan tindakan, observasi dan refleksi. Hasil penelitian yang didapat adalah sebagai berikut : siklus I; Rata-rata hasil belajar siswa 55,47 dan ketuntasan klasikalnya 40\%. Siklus II; Rata-rata hasil belajar siswa 66,01 dan ketuntasan klasikalnya 60\% Siklus III; Rata-rata hasil belajar siswa 74 dan ketuntasan klasikalnya $90 \%$. Berdasarkan hasil analisis data tersebut terdapat peningkatan Rata-rata belajar siswa dan ketuntasan klasikalnya pada tiap siklus. Sehingga dapat disimpulkan bahwa Penerapan Model Pembelajaran Kooperatif Tipe Jigsaw dapat meningkatkan aktivitas dan prestasi belajar siswa pada kelas VIIA semester I SMP Muhammadiyah Mataram tahun pelajaran 2020/2021.
\end{abstract}

Kata Kunci: model pembelajaran kooperatif; pembelajaran Jigsaw; aktivitas belajar; prestasi belajar

\begin{abstract}
This study aims to determine the application of the Jigsaw Cooperative Learning Model to increase student activity and achievement in class VIIA semester I on the subject of Straight Movement at SMP Muhammadiyah Mataram in the 2020/2021 academic year. The type of research used is classroom action research, which consists of three cycles consisting of planning, action, observation and reflection. The research results obtained are as follows: cycle I; The average student learning outcomes are 55.47 and the classical completeness is $40 \%$. Cycle II; The average student learning outcomes are 66.01 and the classical completeness is 60\% Cycle III; The average student learning outcomes are 74 and the classical completeness is $90 \%$. Based on the results of the data analysis, there is an increase in the average student learning and classical completeness in each cycle. So it can be concluded that the application of the Jigsaw Type Cooperative Learning Model can increase student activity and achievement in class VIIA semester I SMP Muhammadiyah Mataram in the 2020/2021 school year.
\end{abstract}

Keywords: cooperative learning model; Jigsaw type; learning activity; learning achievement

\section{PENDAHULUAN}

Belajar pada dasarnya adalah proses yang bermakna untuk mencapai kompetensi atau kecakapan hidup (life skill). Kecakapan hidup merupakan kebutuhan setiap orang, karena itulah belajar merupakan kegiatan untuk membentuk, mengembangkan dan menyempurnakan kecakapan hidup yang akan menjadikan hidupnya lebih bermakna. Makna kehidupan terjadi dalam konteksnya, oleh karena

@ 2021 JagoMipa (https://bimaberilmu.com/jurnal/index.php/jagomipa) 
itu pelajaran akan menjadi bermakna bila dikaitkan dengan konteks kehidupan nyata siswa.

Pembelajaran merupakan suatu kegiatan yang melibatkan seseorang dalam upaya memperoleh pengetahuan, keterampilan, dan nilai-nilai positif dengan memanfaatkan berbagai sumber untuk belajar. Pembelajaran dapat melibatkan dua pihak yaitu siswa sebagai pembelajar dan guru sebagai fasilitator. Yang terpenting dalam pembelajaran adalah terjadiya proses belajar (Learning Process), karena sesuatu bisa dikatakan hasil belajar kalau memenuhi beberapa ciri, diantaranya belajar sifatnya disadari, hasil belajar diperoleh dengan adanya proses, dan belajar membutuhkan interaksi. Begitu pula dengan pembelajaran fisika, berdasarkan pengalaman pembelajaran fisika yang telah dijalankan selama ini hanya menekankan pada ingatan serta hafalan siswa. Selain itu, sumber belajar siswa hanya diperoleh melalui buku-buku yang cukup terbatas. Oleh karena itu pemahaman siswa hanya terbatas pada hafalan serta ingatannya tersebut.

Pemahaman yang terbatas ini mengakibatkan siswa menjadi kurang terampil dan kreatif dalam menghadapi permasalahan (terutama yang berkaitan dengan materi fisika) yang mungkin akan dihadapinya kelak. Prestasi belajar ilmu fisika pada umumnya masih rendah, hal ini disebabkan oleh adanya kesulitan dalam belajar fisika yaitu kesulitan dalam membaca istilah, angka, memahami konsep-konsep menggunakan alat-alat dan disebabkan oleh faktor-faktor prestasi belajar baik factor internal maupun eksternal.

Upaya peningkatan kualitas pembelajaran fisika tidak dapat berhasil dengan maksimal tanpa didukung oleh adanya interaksi antara guru dan siswa. Peluang yang dibawa K13 memberikan keleluasaan kepada guru sebagai pengembang kurikulum dalam tatanan kelas juga belum dapat dimanfaatkan secara optimal, karena keterbatasan kemampuan guru, sehingga berdampak pada munculnya sikap intuitif dan spekulatif dalam menggunakan strategi pembelajaran. Kondisi ini berakibat pada rendahnya mutu hasil belajar. Salah satu cara yang dapat dilakukan dengan kondisi yang kurang menguntungkan itu agar tidak berkelanjutan dan berkembang lebih jauh adalah dengan memberikan persepsi mengenai model pembelajaran yang dipandang kondusif sehingga dapat meningkatkan efektivitas pembelajaran.

Berdasarkan observasi yang saya lakukan dan informasi dari guru fisika di SMP Muhammadiyah Mataram bahwa hanya sebagian kecil siswa melibatkan diri secara aktif dalam proses pembelajaran fisika. Mereka adalah siswa yang pintar sedangkan siswa yang kurang pintar terlihat pasif, sehingga siswa sulit untuk memahami materi yang diajarkan dalam proses pembelajaran dan guru lebih mendominasi pada saat pembelajaran berlangsung. Pada saat guru mengajar, siswa sering berdiskusi dengan temannya tetapi guru jarang memberikan peluang untuk melakukan kegiatan diskusi, selain itu guru fisika di SMP Muhammadiyah Mataram juga belum pernah menggunakan metode pembelajaran kooperatif tipe jigsaw dalam pembelajaran fisika. Akan tetapi dalam mengajarkan materi pelajaran kepada siswa biasanya guru menggunakan metode ceramah dan metode demonstrasi, sehingga dapat menyebabkan masih rendahnya prestasi belajar siswa dan akhirnya berdampak pada rendahnya nilai fisika yang didapat siswa Kelas VII di SMP Muhamadiyah Mataram. Hal ini terlihat dari nilai rata-rata ulangan semester ganjil Tahun Pelajaran 2020/2021, sebagaimana pada tabel berikut ini. 
Tabel 1. Nilai Rata-Rata Ulangan Semester Ganjil Tahun Pelajaran 2020/2021.

\begin{tabular}{|c|c|}
\hline Kelas & Nilai rata-rata \\
\hline VII A & 55.3 \\
\hline VII B & 66.1 \\
\hline
\end{tabular}

Dari data yang tertera di atas bahwa nilai rata-rata yang diperoleh siswa kelas VII A belum mencapai standar Kriteria Ketuntasan Minimal (KKM) yang telah ditetapkan yaitu $\geq 65$. Salah satu upaya yang dapat dilakukan untuk mengatasi rendahnya prestasi belajar fisika dengan menerapkan suatu model pembelajaran kooperatif tipe jigsaw, karena tipe jigsaw ini belum pernah diterapkan di SMP Muhammadiyah Mataram sehingga peneliti mencoba menerapkan model pembelajaran tipe jigsaw.

Berdasarkan hal tersebut, maka dilakukan penelitian dengan judul tentang penerapan model pembelajaran kooperatif tipe jigsaw untuk meningkatkan aktivitas dan prestasi belajar siswa pada kelas VII SMP Muhammadiyah Mataram tahun pelajaran 2020/2021”.

\section{KAJIAN TEORI}

\section{Pembelajaran Fisika di SMP}

Fisika merupakan salah satu cabang sains yang mempelajari gejalagejala alam melalui penelitian, percobaan dan pengukuran yang disajikan secara matematis berdasarkan hukum dasar untuk menemukan hubungan antara kenyataan yang ada di alam . Pembelajaran adalah suatu kegiatan yang dilakukan secara sadar dan sengaja dilakukan oleh guru sedemikian rupa, sehinggah tingkah laku siswa berubah kearah yang lebih baik. Oleh karena itu pembelajaran bertujuan untuk membantu siswa agar memperoleh berbagi pengalaman dan dengan pengalaman itu tingkah laku siswa bertambah, baik kuantitas maupun kualitas. Tingkah laku yang dimaksud adalah meliputi pengetahuan, dan nilai atau norma yang berfungsi sebagai pengendali sikap dan perilaku siswa.

Tujuan pembelajaran sains Fisika di SMP adalah sebagai adalah memberikan pemahaman tentang berbagai macam gejala alam, prinsip dan konsep sains serta keterkaitannya dengan lingkungan, tekhnologi dan masyarakat; memberikan pengalaman kepada siswa dalam merencanakan dan melakukan kerja ilmiah untuk membentuk sikap ilmiah (Gunawan dkk, 2020; Wahidah, 2021).

Karakteristik pembelajaran efektif adalah memudahkan siswa belajar sesuatu yang bermanfaat, seperti: fakta keterampilan, nilai, konsep, dan bagaimana hidup serasi dengan sesama, atau sesuatu hasil yang diinginkan, pengetahuan yang konkrit lebih mudah diterima oleh siswa daripada pengetahuan yang masih abstrak. Dalam kondisi pembelajaran yang kondusif, yang melibatkan siswa secara aktif dalam mengamati, mengoperasikan alat-alat, dan berlatih menggunakan objek yang konkrit disertai dengan diskusi diharapkan siswa dapat bangkit sendiri untuk berfikir, untuk menganalisis data, untuk menjelaskan ide, untuk bertanya, untuk berdiskusi, dan menulis apa yang dipikirkan sehingga memberi kesempatan siswa untuk mengkonstruksikan pengetahuannya sendiri (Nufus, 2021; Syarifuddin dkk, 2021; Khotimah dkk, 2021). 


\section{Model Pembelajaran Kooperatif Pengertian Model Pembelajaran Kooperatif}

Model pembelajaran kooperatif adalah suatu model pembelajaran dimana siswa belajar dan bekerja dalam kelompok-kelompok kecil secara kolaboratif yang anggotanya 4-6 orang dengan struktur kelompok heterogen (Isjoni, 2009; Sutarto \& Syarifuddin, 2013; Syarifuddin, 2018)). Sedangkan menurut Ibrahim (2000) pembelajaran kooperatif merupakan pembelajaran yang dicirikan oleh struktur tugas, tujuan dan penghargaan kooperatif. Siswa yang bekerja dalam situasi pembelajaran kooperatif didorong dan atau dikehendaki untuk bekerja sama pada suatu tugas bersama, dan mereka harus mengkoordinasikan usahanya untuk menyelesaikan tugasnya (Baeti \& Mikrayanti, 2018; Wirahmad dkk, 2020).

Dari beberapa pendapat di atas, dapat disimpulksan mengenai definisi pembelajaran kooperatif adalah pembelajaran yang menempatkan siswa dalam kelompok yang berbeda kemampuan, menyesuaikan tugas bersama dalam kelompok, saling membantu untuk memahami suatu bahan pelajaran sampai seluruh anggota kelompok memahami bahan pelajaran.

\section{Model Pembelajaran Kooperatif Tipe Jigsaw}

Pembelajaran Kooperatif Tipe Jigsaw merupakan salah satu tipe pembelajaran kooperatif yang mendorong siswa aktif dan saling membantu dalam menguasai materi pelajaran untuk mencapai prestasi yang maksimal. Dalam model belajar ini terdapat tahap-tahap dalam penyelenggaraannya (Isjoni, 2009; Syarifuddin, 2015). Teknik Jigsaw yang dikembangkan Aronson Et Al, guru memperhatikan skemata atau latar belakang pengalaman siswa dan membantu siswa mengaktifkan skemata ini agar bahan pelajaran menjadi lebih bermakna. Selain itu, siswa bekerja dengan sesama siswa dalam suasana gotong-royong dan mempunyai banyak kesempatan untuk mengolah informasi dan meningkatkan keterampilan berkomunikasi yang cocok (Isjoni, 2009).

Sedangkan "Menurut Edward kelompok yang terdii dari empat orang terbukti sangat efektif. Sedangkan menurut Sudjana mengemukakan beberapa siswa dihimpun dalam satu kelompok dapat terdiri dari 4-6 orang siswa.Jumlah yang paling tepat menurut slavin adalah hal itu dikarenakan kelompok yang beranggotakan 4-6 orang lebih sepaham dalam menyelesaikan suatu permasalahan di bandingkan dengan kelompok yang beranggotakan 2-4 orang. (Isjoni, 2011)". Tipe jigsaw digunakan untuk mengembangkan keahlian dan keterampilan yang diperlukan untuk menggolongkan aktivitas yaitu mendengarkan, menyampaikan, kerjasama, refleksi dan keterampilan memecahkan masalah. Tipe jigsaw adalah suatu tipe kerja kelompok untuk belajar dan partisipasi dalam kelompok, dengan kegiatan sebagai berikut :

1. Listening (mendengarkan). Siswa aktif mendengarkan dalam materi yang dipelajari dan mampu memberi pengajaran pada kelompok aslinya.

2. Speaking-student (berkata). Akan menjadikan siswa bertanggung jawab menerima pengetahuan dari kelompok baru dan menyampaikannya kepada pendengar baru dari kelompok aslinya.

3. Kerjasama. Setiap anggota dari tiap kelompok bertanggung jawab untuk sukses dari yang lain dalam kelompok

4. Refleksi. Pemikiran yang berhasil melengkapi, menyelesaikan kegiatan dalam kelompok yang asli. 
5. Berfikir kreatif. Setiap kelompok harus memikirkan penyelesaian yang baru dalam mengajarkan dan mempresentasikan materi.

Langkah-Langkah Pembelajaran Kooperatif Dengan tipe Jigsaw :

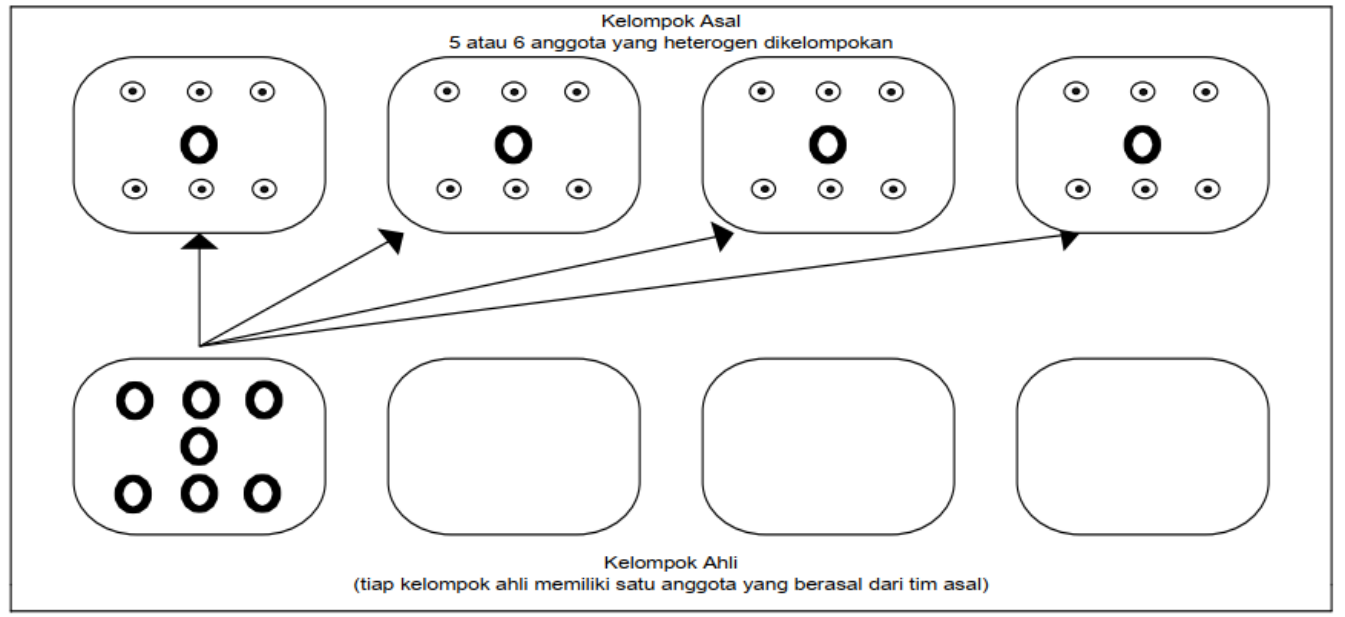

Gambar 1. Kelompok asal dan Kelompok asli Jigsaw

1. Membagi siswa ke dalam kelompok jigsaw dengan jumlah 5-6 orang.

2. Menugaskan satu siswa dari masing-masing kelompok sebagai pemimpin/ketua kelompok, umumnya siswa yang dewasa dalam kelompok itu.

3. Membagi pelajaran yang akan dibahas ke dalam 5-6 segmen. Sebagai contoh membahas tentang alat-alat optik maka dibagi ke dalam segmen: Sebagai contoh membahas tentang alat-alat optik, maka dibagi ke dalam segmen: Mata dan cacat mata serta penanggulanganya, Lup, kamera, mikroskop, teropong dan periskop.

4. Menugaskan tiap siswa untuk mempelajari satu segmen dan untuk menguasai segmen mereka sendiri.

5. Memberikan rentang waktu kepada para siswa itu untuk membaca secepatnya segmen mereka sedikitnya dua kali agar mereka terbiasa dan tidak ada waktu untuk menghafal.

6. Bentuklah kelompok ahli dengan satu orang dari masing-masing kelompok asal bergabung dengan siswa lain yang memiliki segmen yang sama untuk mendiskusikan poin-poin yang utama dari segmen mereka dan berlatih presentasi kepada kelompok asal mereka.

7. Setiap siswa dari kelompok ahli kembali ke kelompok asal mereka.

8. Mintalah masing-masing siswa untuk menyampaikan segmen yang dipelajarinya kepada kelompoknya, dan memberi kesempatan kepada siswa-siswa yang lain untuk bertanya.

9. Guru berkeliling dari kelompok satu ke kelompok yang lainnya, mengamati proses itu. Bila ada siswa yang mengganggu segera dibuat intervensi yang sesuai oleh pemimpin kelompok yang di tugaskan.

10. Pada akhir bagian beri ujian atas materi sehingga siswa tahu bahwa pada bagian ini bukan hanya belajar kelompok tapi benar-benar memahaminya.

Kegiatan pembelajaran kelompok asal dalam tipe jigsaw :

1. Membagi kelompok 5 atau 6 orang yang heterogen. 
2. Membagi pelajaran yang akan dibahas ke dalam 5-6 segmen. Sebagai contoh membahas tentang alat-alat optik maka dibagi ke dalam segmen: Mata dan cacat mata serta penanggulanganya, Lup, kamera, mikroskop, teropong dan periskop.

3. Setiap anggota kelompok membaca segmen yang ditugaskan dan bertanggung jawab untuk mempelajarinya.

4. Dalam kelompok asal dipilih satu orang siswa untuk di masukkan ke kelompok ahli.

Kegiatan pembelajaran kelompok ahli dalam tipe jigsaw:

1. Dalam kelompok ahi terdiri dari satu anggota dari tim asal.

2. Dari setiap anggota kelompok asal yang telah mempelajari segmen bertemu dalam kelompok ahli untuk mendiskusikannya.

3. Setelah diskusi selesai, setiap anggota dari kelompok ahli kembali ke kelompok asal masing - masing bertugas untuk mengajari teman-teman nya.

Berdasarkan uraian diatas, dalam tipe jigsaw ini setiap anggota kelompok ditugaskan untuk mempelajari materi tertentu. Kemudian siswa sebagai perwakilan dari kelompoknya masing-masing bertemu dengan anggota perwakian dari kelompok lain yang mempelajari materi yang sama. Selanjutnya materi tersebut didiskusikan sehingga perwakilan tersebut dapat memahami dan menguasai materi.

\section{Aktivitas Belajar}

Proses belajar mengajar, guru sangat berperan dalam aktivitas belajar siswa karena aktivitas belajar merupakan prinsip atau asas yang sangat penting dalam belajar mengajar. Sistem pembelajaran dewasa ini sangat menekankan pada pendayagunaan asas keaktifan (aktivitas) dalam proses pembelajaran untuk mencapai tujuan yang telah ditentukan (Hamalik, 2001). Aktifnya siswa selama proses belajar mengajar merupakan salah satu indikator adanya keinginan atau motivasi siswa untuk belajar. Siswa dikatakan memiliki keaktifan apabila ditemukan ciri-ciri perilaku seperti sering bertanya kepada guru atau siswa lain, mau mengerjakan tugas yang diberikan oleh guru, mampu menjawab pertanyaan, senang diberi tugas belajar, dan lain sebagainya. Semua ciri perilaku tersebut pada dasarnya dapat ditinjau dari dua segi yaitu segi proses dan dari segi hasil.

Serta keaktifan peserta didik tidak hanya dituntut dari segi fisik tetapi juga dari segi kejiwaan. Bila hanya fisik anak yang aktif, tetapi pikiran dan mentalnya kurang aktif maka kemungkinan besar tujua pembelajaran tidak aktif.

Pengguanaan asas aktivitas dalam proses pembelajaran memiliki manfaat sebagaimana dikemukakan oleh Hamalik (2001) antara lain:

1. Para sisiwa mencari pengalaman sendiri dan langsung mengalami sendiri.

2. Berbuat sendiri akan mengembangkan seluruh aspek pribadi siswa secara integral.

3. Memupuk kerjasama yang harmonis dikalangan siswa.

4. Para siswa belajar dan bekerja menurut minat dan kemampuan sendiri.

5. Memupuk disiplin belajar dan suasana belajar yang demokratis dan kekurangan, musyawarah dan mufakat.

\section{Prestasi Belajar}

Kegiatan belajar mengajar prestasi belajar merupakan hal yang sangat penting, karena dapat menjadi petunjuk sejauh mana keberhasilan seorang. Prestasi belajar, merupakan gambaran keberhasilan seorang guru dalam mengajar dan gambaran seorang siswa dalam belajar. Menurut Slameto (2003) belajar adalah suatu proses 
usaha yang dilakukan seseorang untuk memperoleh sesuatu perubahan tingkah laku yang baru secara keseluruhan sebagai hasil pengalamannya sendiri dalam interaksi dengan lingkungannya. Sedangkan (Djamara, 2000) mengatakan belajasr adalah suatu aktifitas yang dilakukan secara sadar untuk mendapatkan sejumlah kesan dari bahan yang telah dipelajari. Hasil dari aktivitas belajar terjadilah perubahan dalam diri individu. Dengan demikian, belajar dikatakan berhasil bila telah terjadi perubahan dalam diri individu. Pendapat di atas dapat disimpulkan bahwa belajar merupakan proses perubahan tingkah laku dari pengalaman dan latihan. Perubahan tingkah laku, baik yang menyangkut pengetahuan, keterampilan maupun sikap bahkan meliputi segenap aspek organisasi atau pribadi. Kegiatan belajar mengajar seperti mengorganisasi pengalaman belajar kesemuanya termasuk kedalam cakupan tanggung jawab guru. Djamarah (2000) mengemukakan bahwa prestasi belajar adalah penilaian pendidikan tentang kemajuan siswa dalam segala hal yang dipelajari di sekolah yang menyangkut pengetahuan dan percakapan/keterampilan yang dinyatakan sesudah hasil penilaian. Proses belajar mengajar supaya berhasil sesuai dengan tujuan yang ingin dicapai perlu memperhatikan dua faktor yang mempengaruhi prestasi belajar yaitu faktor internal dan faktor eksternal (Slameto, 2003).

\section{METODE PENELITIAN}

Jenis penelitian ini termasuk penelitian tindakan kelas (Classroom Action Research) dengan tahapan-tahapan pelaksanaan meliputi: perencanaan, tindakan, observasi, evaluasi dan refleksi yang selanjutnya tahapan-tahapan tersebut dirangkai dalam tiga siklus kegiatan. PTK adalah suatu bentuk kajian yang bersifat refleksi oleh pelaku tindakan yang dilakukan untuk meningkatkan kemantapan rasional pemahaman terhadap tindakan yang dilakukan itu, serta memperbaiki kondisi dimana praktik pembelajaran tersebut dilakukan.

Adapun pendekatan penelitian yang digunakan dalam penelitian ini adalah pendekatan penelitian kuantitatif dan kualitatif. Pendekatan kuantitatif dalam penelitian ini digunakan untuk mengolah data hasil belajar dan pendekatan kualitatif digunakan untuk mengolah data hasil observasi.

\section{Rancangan Penelitian}

Rancangan yang dimaksud adalah tindakan kelas berupa peningkatan prestasi belajar dan aktivitas siswa dalam pembelajaran fisika pada siswa Kelas VII SMP Muhammadiyah Mataram Tahun Pelajaran 2020/2021. Untuk meningkatkan kinerja atau aktivitas dan prestasi belajar siswa digunakan tindakan berulang atau siklus yang terdiri dari perencanaan, pelaksanaan tindakan, observasi, Evaluasi dan refleksi. Pada penelitian ini rencana tindakan maksimal 3 siklus yang setiap siklus terdiri dari 1 kali pertemuan.

Adapun gambaran per siklusnya adalah sebagai berikut: 


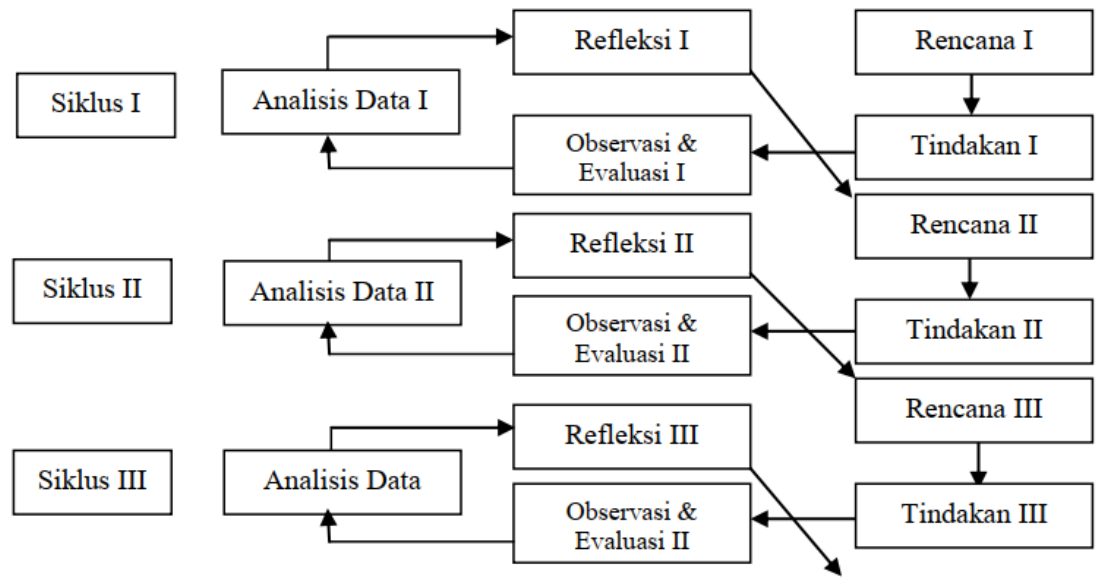

Gambar 2. Spiral Siklus PTK (Arikunto, 2006)

Tahapan-tahapan yang dilakukan dalam perencanaan penelitian ini adalah sebagai berikut:

\section{Tahap Siklus Pertama}

a. Perencanaan.

Tahap ini, hal-hal yang dilakukan oleh peneliti adalah:

1) Menyusun rencana pelaksanaan pembelajaran

2) Membuat lembar kegiatan praktikum

3) Membuat lembaran observasi

4) Mendesai alat evaluasi dan merencanakan analisis hasil tes.

b. Pelaksanaan Tindakan

Tahap pelaksanaan tindakan dilakukan pembelajaran sesuia dengan skenario dan rencana pembelajaran yang telah disusun.

c. Observasi dan Evaluasi

Kegiatan obervasi dilakukan secara kontinyu setiap kali pembelajaran berlangsung, dalam pelaksanaan tindakan dengan mengamati kegiatan guru dan aktivitas siswa. Sedangkan evaluasi dilakukan dengan memberikan tes dengan bentuk soal pilihan ganda kepada siswa.

d. Refleksi

Hasil yang diperoleh dari hasil observasi dan hasil evaluasi belajar siswa dikumpulkan serta dianalisis, sehingga dari hasil tersebut guru dapat merefleksi diri dengan melihat data observasi, yaitu; identifikasi kekurangan, analisis sebab kekurangan dan menentukan perbaikan pada siklus berikutnya.

\section{Tahap Siklus II dan Siklus III}

Pelaksanaan siklus kedua ini urutannya sama dengan pelaksanaan pada siklus pertama dan tindakan yang dilakukan pada siklus kedua ini berdasarkan hasil analisis tes pada siklus pertama. Begitu pula pada siklus ketiga, hanya pada tindakan yang dilakukan berdasarkan hasil analisis tes pada siklus kedua

\section{Teknik Pengumpulan Data}

Cara pengambilan data dalam penelitian ini adalah:

1. Data tentang situasi belajar mengajar dan kinerja atau aktivitas siswa didapat dari lembaran observasi. 
2. Data hasil belajar siswa diperoleh dengan cara memberikan tes evaluasi pada siswa setiap akhir siklus.

\section{Instrumen Penelitian}

Instrument atau alat ukur yang disusun adalah instrument yang digunakan untuk menilai proses dan menilai hasil belajar dalam penilaian tindakan kelas (PTK) ini adalah:

\section{Lembar Observasi}

Observasi diartikan sebagai pengalaman dan pencatatan secara sistimatik terhadap gejala yang tampak pada objek penelitian. Pengamatan dan pencatatan yang dilakukan terhadap objek di tempat terjadi atau berlangsungnya peristiwa, sehingga observer berada bersama objek yang diselidiki, disebut observasi langsung. Sedangkan observasi tidak langsung adalah pengamatan yang dilakukan tidak pada saatnya berlangsungnya suatu peristiwa yang akan diselidiki, misalnya peristewa tersebut diamati melalui film, rangkaian slide atau rangkaian foto (Haryono, 2005). Berdasarkan pernyataan di atas, maka penelitian ini dikategorikan dalam observasi langsung. Lembar observasi akan digunakan untuk mengamati terlaksananya seluruh langkah proses belajar mengajar (PBM) yang direncanakan di dalam rencana pelaksanaan pembelajaran yang telah disusun oleh peneliti.

Tes

Menurut Arikunto (2006), instrumen penelitian adalah alat atau fasilitas yang digunakan oleh peneliti dalam mengumpulkan data agar pekerjaannya lebih mudah dan hasilnya lebih baik, dalam arti lebih cermat, lengkap dan sistematis sehingga lebih mudah diolah. Instrumen yang digunakan dalam penelitian ini adalah berupa seperangkat soal dalam bentuk pilihan ganda.

\section{Tehnik Analisis Data}

\section{Aktivitas Siswa}

Peningkatan kinerja atau aktivitas siswa dapat diketahui melalui hasil observasi terhadap perilaku siswa selama mengikuti proses pengamatan. Aktivitas belajar siswa diamati dan dicatat dengan mengguakan lembar observasi, yakni terdiri dari pemilihan topik pelajaran, diskusi kelompok, menginformasikan hasil diskusi, mengkomunikasikan dan menyimpulkannya. Kualifikasi aktivitas siswa ditentukan berdasarkan pedoman konversi pada tabel berikut:

Tabel 2. Pedoman Konversi Penilaian Skala 1-5 Aktivitas Siswa Dalam Mangikuti Pembelajaran:

\begin{tabular}{|l|l|l|}
\hline Interval & Nilai & Kualifikasi \\
\hline $\mathrm{M}_{i}+1,5 \mathrm{SD}_{\mathrm{i}}<\mathrm{A}$ & $4,5<\mathrm{A}$ & Sangat aktif \\
$\mathrm{M}_{\mathrm{i}}+0,5 \mathrm{SD}_{\mathrm{i}}<\mathrm{A} \leq \mathrm{M}_{i}+1,5 \mathrm{SD}_{\mathrm{i}}$ & $3,5<\mathrm{A} \leq 4,5$ & Aktif \\
$\mathrm{M}_{\mathrm{i}}-0,5 \mathrm{SD}_{\mathrm{i}}<\mathrm{A} \leq \mathrm{M}_{\mathrm{i}}+0,5 \mathrm{SD}_{\mathrm{i}}$ & $2,5<\mathrm{A} \leq 3,5$ & Cukup aktif \\
$\mathrm{M}_{\mathrm{i}}-1,5 \mathrm{SD}_{\mathrm{i}}<\mathrm{A} \leq \mathrm{M}_{\mathrm{i}}-0,5 \mathrm{SD}_{\mathrm{i}}$ & $1,5<\mathrm{A} \leq 2,5$ & Kurang aktif \\
$\mathrm{A} \leq \mathrm{M}_{\mathrm{i}}-1,5 \mathrm{SD}_{\mathrm{i}}$ & $\mathrm{A} \leq 1,5$ & Sangat kurang aktif \\
\hline
\end{tabular}

(Nurkancana, 2000).

Untuk data aktivitas siswa dikatakan berhasil apabila rata-rata skor siswa untuk setiap aktivitas termasuk pada kriteria aktif, dan sangat aktif.

\section{Data Tes Hasil Belajar}

1. Ketuntasan Individual 
Setiap siswa dalam proses belajar-mengajar dikatakan terampil dalam menyelesaikan masalah secara tuntas apabila memperoleh nilai 65. Nilai ketuntasan minimal sebesar 65 dipilih karena sesuai kemampuan individu (Ridwan, 2005).

2. Ketuntasan Klasikal

Data hasil belajar dalam proses pembelajaran di analisis dengan menggunakan analisis ketuntasan hasil belajar secara klasikal minimal $85 \%$ dan jumlah siswa yang memperoleh nilai 65 (Ridwan, 2005). Sehingga rumus ketuntasan belajar klasikal adalah:

Dimana:

$$
\mathrm{KK}=\frac{X}{Z} \times 100 \%
$$

KK = Ketuntasan Klasikal

$\mathrm{X}=$ Jumlah siswa yang memperoleh nilai 65

$\mathrm{Z}=$ Jumlah seluruh siswa

Ketuntasan siswa dalam menyelesaikan tercapai jika 85\% siswa memperoleh skor minimal 65 yang akan terlihat pada hasil evaluasi tiap siklus.

\section{HASIL DAN PEMBAHASAN}

\section{Hasil Penelitian}

\section{Analisis Data Penelitian Siklus 1}

Pada siklus ini, guru melaksanakan pembelajaran pada materi pokok Gerak Lurus yang diawali dengan tahap perencanaan, pelaksanaan tindakan, kemudian observasi dan refleksi.

a) Hasil observasi aktivitas belajar siswa siklus I

Tabel 3. Hasil Observasi Aktiviatas Belajar Siswa

\begin{tabular}{|c|c|c|c|c|}
\hline $\begin{array}{c}\text { Siklus } \\
1\end{array}$ & Banyak Siswa & $\begin{array}{c}\text { Skor } \\
\text { Total }\end{array}$ & Rata-rata & Kategori \\
\hline Pert 1 & 20 & 273 & 13.65 & C.Aktif \\
\hline \multicolumn{3}{|c|}{ Skor rata-rata siklus I } & 13.65 & C.Aktif \\
\hline
\end{tabular}

Berdasarkan hasil observasi belajar siswa di atas dapat dilihat bahwa pada pertemuan 1 jumlah siswa 20 dan ratarata aktivitas siswa sebesar 13.65, ini berarti kategori aktivitas siswa tergolong cukup aktif.

b) Hasil Obseravasi Aktivitas Guru Siklus I

Penilaian aktivitas guru pun dilakukan pada setiap kali pertemuan. Adapun hasil yang diperoleh dari observasi terhadap aktivitas guru dapat dilihat dalam tabel berikut :

Tabel 4. Hasil Observiasi Aktivitas Guru

\begin{tabular}{|c|c|c|}
\hline Jumlah Skor & Rata-rata & Kategori \\
\cline { 1 - 2 } Pertemuan 1 & 12 & \multirow{2}{*}{ Cukup Aktif } \\
\hline 12 & & \\
\hline
\end{tabular}

Berdasarkan kriteria penggolognan aktivitas guru pada pembelajaran siklus 1 diperoleh rata-rata aktivitas guru selama proses pembelajaran di dalam kelas sebesar 12, hal ini berarti kategori aktivitas guru tergolong cukup aktif.

c) Evaluasi Pembelajaran Siklus I

Setelah melakukan observasi maka dilanjutkan dengan evaluasi. Adapun hasil evaluasi yang diperoleh pada siklus 1 dapat dilihat pada tabel berikut ini. 
Tabel 5. Hasil Evaluasi Pembelajaran

\begin{tabular}{|c|l|c|}
\hline No & \multicolumn{1}{|c|}{ Hasil Evaluasi } & Keterangan \\
\hline 1 & Jumlah siswa & 20 \\
\hline 2 & Siswa yang mengikuti tes & 20 \\
\hline 3 & Siswa yang tidak mengikuti tes & 0 \\
\hline 4 & Siswa tuntas secara individu & 8 \\
\hline 5 & Siswa tidak tuntas secara individu & 12 \\
\hline 6 & Rata-rata nilai siswa & 55,45 \\
\hline 7 & \% ketuntas klasikal & $40 \%$ \\
\hline
\end{tabular}

Berdasarkan tabel 5 diatas dapat diketahui bahwa siswa yang mengikuti evaluasi 20 orang dari jumlah siswa 20 orang. Hasil evaluasi siklus 1 menunjukkan bahwa nilai rata-rata siswa adalah 55,45 dengan persentase ketuntasan klasikal $40 \%$. Hal ini dapat dikatakan bahwa nilai rata-rata dan ketuntasan klasikal pembelajaran pada siklus 1 belum memenuhi standar atau belum 36 tuntas, karena ketuntasan klasikal tercapai apabila siswa yang tuntas $\geq 85 \%$. Oleh kaarena itu, perlu dilakukan perbaikan pada siklus berikutnya.

d) Refleksi

Refleksi dilakukan pada akhir siklus. Pada tahapan ini peneliti bersama observer mengkaji pelaksanaan dan hasil yang diperoleh dalam pemberian tindakan pada siklus 1. Sebagai acuan pada siklus ini adalah hasil observasi dan evaluasi. Hasil evaluasi ini digunakan sebagai dasar untuk memperbaiki serta menyempurnakan perencanaan dalam pelaksanaan tindakan pada siklus berikutnya. Dilihat dari hasil yang diperoleh pada siklus I masih belum mencapai hasil yang diharapkan.

Adapun kekurangan-kekurangan yang terdapat pada siklus 1 yang diperoleh dari hasil observasi kegiatan pembelajaran di dalam kelas maupun dari hasil evaluasi siswa pada akhir siklus adalah sebagai berikut : (1) Pada saat kerja kelompok siswa masih terlihat bekerja sendiri-sendiri belum ada saling tukar pendapat antar sesama kelompok (2) Pada saat diskusi kelompok siswa belum ada keantusiasan hanya beberapa yang berani memberikan tanggapan sedangkan yang lain lebih banyak diam. 37 (3) Siswa lebih banyak mendengarkan guru daripada mengemukakan pendapat mereka sendiri. (4) Siswa masih banyak yang ragu-ragu dalam merespon pelajaran, belum ada yang berani maju mengerjakan latihan yang diberikan di papan tulis. (5) Siswa masih kesulitan dalam menyimpulkan materi yang dibahas. (6) Sebagian siswa belum terbiasa menciptakan suasana pembelajaran yang mengarah pada Model pembelajaran kooperatif tipe Jigsaw. (7) Pengelolaan kelas oleh guru (peneliti) masih kurang. (8) Belum adanya pemberian penguatan terhadap materi yang telah dibahas oleh siswa, dan belum ada ketegasan dalam batasan-batasan selama kegiatan pembelajaran berlangsung. (9) Siswa masih kesulitan dalam memahami soal evaluasi yang diberikan sehingga ada beberapa soal yang tidak terselesaikan. Kekurangan-kekurangan yang terjadi pada siklus 1 ini menyebabkan pelaksanaan tindakan pada siklus 1 belum sesuai dengan harapan yang ingin dicapai oleh peneliti sehingga dilakukan perbaikan pada siklus dua.

\section{Siklus II}

Hasil penelitian siklus II merupakan perbaikan dan kelanjutan dari siklus I dimana tahap pelaksanaan penelitian siklus II sama dengan siklus I.

a) Hasil Observasi Aktivitas siswa 
Data lengkap mengenai aktivitas belajar siswa selama proses pembelajaran pada siklus II. Berdasarkan hasil observasi siklus II dari satu kali pertemuan skor rata-rata siswa dapat dilihat pada tabel berikut :

Hasil Observasi Aktivitas Siswa Siklus II

Tabel 6. Hasil Observasi Aktivitas Belajar Siswa

\begin{tabular}{|c|c|c|c|c|}
\hline Siklus 1I & Banyak Siswa & $\begin{array}{c}\text { Skor } \\
\text { Total }\end{array}$ & Rata-rata & Kategori \\
\hline Pert 1 & 20 & 286 & 14.3 & Cukup Aktif \\
\hline \multicolumn{2}{|r|}{ Skor rata-rata siklus II } & 14.3 & Cukup Aktif \\
\hline
\end{tabular}

Berdasarkan kriteria penggolongan aktivitas belajar siswa yang telah ditetapkan, rata-rata aktivitas siswa sebesar 6, hal ini berarti bahwa kategori aktivitas siswa cukup aktif.

b) Hasil Observasi Aktivitas Guru Siklus II

Penilaian aktivitas guru pun dilakukan pada setiap kali pertemuan. Adapun hasil yang diperoleh dari observasi terhadap aktivitas guru dapat dilihat dalam tabel berikut.

Tabel 7. Hasil Observasi Aktivitas Guru

\begin{tabular}{|l|c|c|}
\hline \multicolumn{1}{|c|}{ Jumlah Skor } & Rata-rata & Kategori \\
\cline { 1 - 1 } Pertemuan 1 & 13 & Cukup Aktif \\
\hline 13 & & \\
\hline
\end{tabular}

Berdasarkan kriteria penggolongan aktivitas guru pada pembelajaran siklus II diperoleh rata-rata aktivitas guru selama proses pembelajaran di dalam kelas sebesar 13, hal ini berarti kategori aktivitas guru tergolong cukup aktif.

c) Evaluasi Pembelajaran

Berdasarkan hasil evaluasi yang telah dilaksanakan diperoleh data seperti pada tabel berikut :

Tabel 8. Hasil Evaluasi Pembelajaran.

\begin{tabular}{|l|l|l|}
\hline No & \multicolumn{1}{|c|}{ Hasil Evaluasi } & \multicolumn{1}{|c|}{ Keterangan } \\
\hline 1 & Jumlah siswa & 20 \\
\hline 2 & Siswa yang mengikuti tes & 20 \\
\hline 3 & Siswa yang tidak mengikuti tes & 0 \\
\hline 4 & Siswa tuntas secara individu & 12 \\
\hline 5 & Siswa tidak tuntas secara individu & 8 \\
\hline 6 & Rata-rata nilai siswa & 66.01 \\
\hline 7 & $\%$ ketuntas klasikal & $60 \%$ \\
\hline
\end{tabular}

Berdasarkan tabel 4.6 diatas dapat diketahui bahwa jumlah siswa yang mengikuti evaluasi sebanyak 20 orang. Hasil evaluasi siklus II menunjukkan bahwa nilai rata-rata siswa sebesar 66,01. dengan persentase ketuntasan klasikal sebesar 60 $\%$. Maka pada siklus II ini kegiatan pembelajaran belum mencapai ketuntasan yang diharapkan.

d) Refleksi

Berdasarkan hasil observasi dan evaluasi siklus II tentang aktivitas dan prestasi belajar siswa menunjukkan bahwa masih banyak kekurangan-kekurangan yang muncul. Oleh karena itu perlu dilakukan perbaikan pada siklus berikutnya. Adapun rencana perbaikan yang dilakukan pada siklus selanjutnya agar memperoleh hasil yang lebih baik adalah sebagai berikut: (1) Guru menyiapkan sumber dan model 
pembelajaran yang lebih baik (2) Menyiapkan ruang lebih awal sehingga waktu tidak terbuang hanya untuk penataan ruang. (3) Guru memantapkan kembali perencanaan dan pelaksanaan model pembelajaran kooperatif tipe Jigsaw baik dari segi waktu maupun pemberian materi. (4) Guru hendaknya lebih menguji pemahaman siswa terhadap materi sebelumnya. (5) Guru menekankan atau menghimbau kepada siswa untuk berdiskusi dan mengikuti pelajaran.

\section{Siklus III}

Siklus III ini merupakan perbaikan dan kelanjutan dari siklus II dimana tahap pelaksanaan penelitian siklus III sama dengan siklus II yaitu perencanaan, tahap pelaksanaan tindakan, tahap observasi, evaluasi dan refleksi pada akhir tindakan.

a) Hasil Observasi Aktivitas Siswa

Berdasarkan hasil observasi siklus III dari dua kali pertemuan skor rata-rata siswa dapat dilihat pada tabel berikut.

Hasil Observasi Aktivitas Siswa Siklus III

Tabel 9. Hasil Observasi Aktivitas Belajar

\begin{tabular}{|c|c|c|c|c|}
\hline Siklus III & $\begin{array}{c}\text { Banyak } \\
\text { Siswa }\end{array}$ & Skor Total & Rata-rata & Kategori \\
\hline Pert 1 & 20 & 393 & 19.65 & Sangat Aktif \\
\hline Pert 2 & 20 & 403 & 20.15 & Sangat Aktif \\
\hline \multicolumn{3}{|c|}{ Skor rata-rata siklus III } & 19.90 & Sangat Aktif \\
\hline
\end{tabular}

Berdasarkan kriteria penggolongan aktivitas belajar siswa yang telah ditetapkan, rata-rata aktivitas siswa sebesar 19,10, hal ini berarti bahwa kategori aktivitas siswa sangat aktif.

b) Hasil Observasi Aktivitas Guru Siklus III

Penilaian aktivitas guru pun dilakukan pada setiap kali pertemuan. Adapun hasil yang diperoleh dari observasi terhadap aktivitas guru dapat dilihat dalam tabel berikut :

Tabel 10. Hasil Observasi Aktivitas Guru

\begin{tabular}{|c|c|c|c|}
\hline \multicolumn{2}{|c|}{ Jumlah Skor } & Rata-rata & Kategori \\
\hline Pertemuan 1 & Pertemuan 2 & 14.5 & Aktif \\
\hline 14 & 15 & & \\
\hline
\end{tabular}

Berdasarkan kriteria penggolongan aktivitas guru pada pembelajaran siklus III diperoleh rata-rata aktivitas guru selama proses pembelajaran di dalam kelas sebesar 14.5, hal ini berarti kategori aktivitas guru tergolong aktif.

c) Evaluasi Pembelajaran

Berdasarkan hasil evaluasi yang telah dilaksanakan diperoleh data seperti pada tabel berikut.

Tabel 11. Hasil Evaluasi pembelajaran.

\begin{tabular}{|l|l|c|}
\hline No & Hasil Evaluasi & Keterangan \\
\hline 1 & Jumlah siswa & 20 \\
\hline 2 & Siswa yang mengikuti tes & 20 \\
\hline 3 & Siswa yang tidak mengikuti tes & 0 \\
\hline 4 & Siswa tuntas secara individu & 18 \\
\hline 5 & Siswa tidak tuntas secara individu & 2 \\
\hline 6 & Rata-rata nilai siswa & 74 \\
\hline 7 & \% ketuntas klasikal & $90 \%$ \\
\hline
\end{tabular}


Berdasarkan tabel 11 diatas menunjukkan bahwa hasil belajar siswa pada siklus III ini mengalami peningkatan. Hal ini dapat dilihat dari rata-rata nilai siswa sebesar 74 dan persentasi ketuntasan klasikal sebesar 90\%, maka pada siklus III ini kegiatan pembelajaran sudah memenuhi standar atau tuntas. Hal ini disebabkan oleh keterlaksanaan RPP, aktivitas siswa, serta aktivitas guru yang meningkat pula.

d) Refleksi

Proses belajar-mengajar telah sesuai dengan rencana pelaksanaan pembelajaran dan hasil evaluasi telah mencapai ketuntasan yang di tetapkan sehingga penelitian ini diakhiri.

\section{PEMBAHASAN}

Penelitian tindakan kelas ini menerapkan model pembelajaran kooperatif tipe Jigsaw dilaksanakan dalam tiga siklus. Pada siklus I ini guru memberikan materi tentang Gerak Lurus dengan menerapkan model pembelajaran kooperatif tipe Jigsaw yaitu pembelajaran kelompok dengan anggota kelompok berjumlah 4-6 orang yang dibagi dalam kelompok asal dan ahli, pada siklus I ini kelompok disusun secara acak.

Tahap perencanaan siklus I dilakukan persiapan-persiapan seperti membuat rencana pembelajaran, membentuk kelompok asal dan kelompok ahli, menyiapkan lembar observasi untuk mencatat aktivitas siswa dan guru selama pembelajaran berlangsung, menyiapkan lembar kerja siswa (LKS) sebagai bahan diskusi kelompok asal dan ahli, dan menyiapkan alat evaluasi. Pelitian ini dilanjutkan pada tahap pelaksanaan dilakukan dengan dua kali pertemuan denagn rincian satu kali pertemuan untuk kegiatan pembelajaran berlangsung selama 2 x 45 menit, kemudian dilanjutkan dengan satu kali pertemuan untuk evaluasi.

Selama proses pembelajaran berlangsung dilakukan observasi terhadap aktivitas siswa dan guru yang dicatat dalam lembar observasi. Berdasarkan analisis data hasil observasi pada siklus I menunjukan bahwa skor rata-rata aktivitas siswa dalam mengikuti proses pembelajaran adalah 13,65, ini menunjukan sebagian besar siswa cukup aktif dalam kegiatan proses belajar mengajar namun belum memenuhi syarat berdasarkan pedoman standar keaktivan yaitu keaktivan siswa dalam proses belajar mengajar kategori aktif.

Setelah proses pembelajaran dilaksanakan, pada akhir pembelajaran dilakukan evaluasi. Dari hasil evaluasi diperoleh nilai rata-rata hasil belajar siswa 55,45 dengan presentase ketuntasan belajar $40 \%$. Hal ini menunjukan syarat ketuntasan belajar belum tercapai yaitu minimal $85 \%$ siswa yang mendapat nilai $\geq 65$. Setelah dilakukan refleksi ternyata hasil observasi aktivitas siswa dan hasil evaluasi, menunjukan bahwa pada siklus I aktivitas siswa dan hasil belajar belum tercapai sesuai dengan yang diharapkan sehingga perlu dilakukan perbaikan pada siklus II.

Ada beberapa kekurangan pada siklus I ini sehingga menyebabkan prestasi belajar siswa belum mencapai ketuntasan yang diharapkan dari hasil observasi aktivitas siswa dan guru selama proses pembelajaran berlangsung yaitu sebagai berikut: (1) Pada saat kerja kelompok siswa masih terlihat bekerja sendiri-sendiri belum ada saling tukar pendapat antar sesama kelompok. (2) Pada saat diiskusi kelompok siswa belum ada keantusiasan hanya beberapa yang berani memberikan tanggapan sedangkan yang lain lebih bayak diam. (3) Siswa lebih banyak mendengarkan guru daripada mengemukakan pendapat mereka sendiri. (4) Siswa masih banyak yang ragu-ragu dalam merespon pelajaran, belum ada yang berani maju mengerjakan latihan yang diberikan dipapan tulis. (5) Siswa masih kesulitan 
dalam menyimpulkan materi yang dibahas. (6) Sebagian siswa belum terbiasa menciptakan suasana pembelajaran yang mengarah pada Model pembelajaran kooperatif tipe Jigsaw (7) Pengelolaan kelas oleh guru (peneliti) yang masih kurang. (8) Belum adanya pemberian penguatan terhadap materi yang telah dibahas oleh siswa, dan belum ada ketegasan dalam batasan-batasan selama kegiatan pembelajaran berlangsung. (9) Siswa masih kesulitan dalam memahami soal evaluasi yang diberikan sehingga ada beberapa soal yang tidak terselesaikan.

Berdasarkan kekurangan-kekurangan yang diperoleh pada hasil refleksi siklus I, maka pada siklus II dilakukan perbaikan dan penyempurnaan kegiatan pembelajaran dengan berpatokan pada kendalakendala yang terjadi pada siklus I. Perbaikan dan penyempurnaan tersebut antara lain sebagai berikut : (1) Agar siswa-siswa lebih aktif dalam diskusi kelompok baik dari segi kerja sama dengan anggota kelompok maupun saling bertukar pendapat dalam mengerjakan tugas kelompok yang diberikan, maka peneliti mengganti struktur kelompok dari kelompok berdasarkan nilai evaluasi pada siklus I. (2) Agar diskusi kelompok menjadi lebih menarik dan siswa-siswa menjadi lebih berani mmemberikan tanggapan dalam kegiatan diskusi kelompok, maka guru memotivasi siswa dengan memberikan penghargaan bagi siswa maupun kelompok yang aktif dalam kegiatan diskusi tersebut. (3) Agar siswa-siswa tidak hanya mendengarkan penjelasan dari guru saja dan mau mengemukakan pendapat mereka sendiri maka guru (peneliti) memberikan pertanyaan-pertanyaan kepada siswa tentang materi yang di bahas. (4) Guru memberikan semangat kepada siswa agar tidak takut untuk mengerjakan latihan-latihan yang diberikan di papan tulis walaupun jawabannya salah. (5) Guru membantu siswa dalam menyimpulkan materi yang dibahas. (6) Agar siswa mampu menciptakan suasana pembelajaran yang mengarah kepada Model pembelajaran kooperatif tipe Jigsaw, guru menjelaskan kembali tujuan pembelajaran kooperatif dan kegiatan-kegiatan dalam pembelajaran kooperatif tipe Jigsaw lebih sensitif membimbing kelompok belajar yang mengalami kesulitan. (7) Guru (peneliti) berusaha untuk lebih meningkatkan lagi pengelolaan kelas dengan cara lebih tegas lagi dalam mendisiplinkan siswa untuk menerima pelajaran dengan baik. (8) Guru (peneliti) akan lebih mempertegas lagi batasan-batasan pembelejaran memberikan penguatan terhadap materi yang telah dibahas oleh siswa. (9) Memperbanyak latihan-latihan soal untuk dikerjakan secara kelompok maupun individu, dan membuat soal-soal evaluasi yang sesuai dengan latihan yang telah diberikan.

Adapun tindakan yang dilakukan pada siklus II pada prinsipnya sama dengan tindakan pada siklus I yaitu tahap perencanaan, tahap pelaksanaan tindakan, tahap observasi, evaluasi, dan refleksi pada akhir tindakan. Pada tahap pelaksanaan ini dilakukan persiapan-persiapan seperti membuat rencana pembelajaran, membentuk kelompok asal dan kelompok ahli, menyiapkan lembar observasi untuk mencatat aktivitas siswa dan guru selama pembelajaran berlangsung, menyiapkan lembar kerja siswa (LKS) sebagai bahan diskusi kelompok asal dan ahli, dan menyiapkan alat evaluasi dan analisis hasil evaluasi. Pelaksanaan tindakan pada siklus II ini sama dengan siklus I, namun pada siklus II ini dilakukan perbaikan-perbaikan sesuai dengan perencanaan yang tlah dibuat pada siklus sebelumnya, Selama proses pembelajaran berlangsung dilakukan observasi terhadap aktivitas siswa dan guru yang dicatat pada lembar observasi. Hasil observasi menunjukan bahwa skor ratarata aktivitas siswa dalam proses pembelajaran sebesar 14,30 , ini berarti sebagian 
besar siswa cukup aktif dalam kegiatan belajar mengajar dan belum memenuhi sarat berdasarkan pedoman standar keaktipan yaitu keaktivan siswa dalam proses belajar mengajar berkategori sangat aktif. Setelah proses pembelajaran dilaksanakan, pada akhir pembelajaran dilakukan evaluasi. Dari hasil evaluasi diperoleh nilai rata-rata hasil belajar siswa 66,01 dengan presentase ketuntasan belajar $60 \%$. Hal ini menunjukan syarat ketuntasan belajar belum tercapai yaitu minimal $85 \%$ siswa yang mendapat nilai $\geq 65$. Setelah dilakukan refleksi ternyata hasil observasi aktivitas siswa dan hasil evaluasi, menunjukan bahwa pada siklus II aktivitas siswa dan hasil belajar belum tercapai sesuai dengan yang diharapkan sehingga perlu dilakukan perbaikan pada siklus III. Ada beberapa kekurangan pada siklus II ini sehingga menyebabkan prestasi belajar siswa belum mencapai ketuntasan yang diharapkan dari hasil observasi aktivitas siswa dan guru selama proses pembelajaran berlangsung yaitu sebagai berikut. Berdasarkan hasil observasi dan evaluasi siklus II tentang aktivitas dan prestasi belajar siswa menunjukkan bahwa masih banyak kekurangankekurangan yang muncul. Oleh karena itu perlu dilakukan perbaikan pada siklus berikutnya.

Adapun rencana perbaikan yang dilakukan pada siklus selanjutnya agar memperoleh hasil yang lebih baik adalah sebagai berikut: (1) Guru menyiapkan sumber dan model pembelajaran yang lebih baik (2) Menyiapkan ruang lebih awal sehingga waktu tidak terbuang hanya untuk penataan ruang. (3) Guru memantapkan kembali perencanaan dan pelaksanaan model pembelajaran kooperatif tipe Jigsaw baik dari segi waktu maupun pemberian materi. (4) Guru hendaknya lebih menguji pemahaman siswa terhadap materi sebelumnya. (5) Guru menekankan atau menghimbau kepada siswa untuk berdiskusi dan mengikuti pelajaran.

Penelitian pada siklus III ini dilakukan tiga kali pertemuan dengan rincian dua kali pertemuan untuk kegiatan pembelajaran berlangsung selama 2 x 45 menit, kemudian dilanjutkan dengan satu kali pertemuan untuk evaluasi hasil belajar. Pada siklus III ini guru memberikan materi tentang Gerak Lurus Berubah Beraturan dengan berpatokan pada rencana-rencana perbaikan yang telah direncanakan pada refleksi siklus II. Adapun langkah-langkah pelaksanaan tersaji pada rencana pelaksanan pembelajaran yang telah dirancang.

Pada tahap pelaksanaan ini dilakukan persiapan-persiapan seperti membuat rencana pembelajaran, membentuk kelompok asal dan kelompok ahli, menyiapkan lembar observasi untuk mencatat aktivitas siswa dan guru selama pembelajaran berlangsung, menyiapkan lembar kerja siswa (LKS) sebagai bahan diskusi kelompok asal dan ahli, dan menyiapkan alat evaluasi dan analisis hasil evaluasi yang (Rukmini \& Ningsi, 2021).

Pelaksanaan tindakan pada siklus III ini sama dengan siklus II, namun pada siklus III ini dilakukan perbaikan-perbaikan sesuai dengan perencanaan yang tlah dibuat pada siklus sebelumnya, Selama proses pembelajaran berlangsung dilakukan observasi terhadap aktivitas siswa dan guru yang dicatat pada lembar observasi. Hasil observasi menunjukan bahwa skor rata-rata aktivitas siswa dalam proses pembelajaran sebesar 20.20, ini berarti sebagian siswa sangat aktif dan skor rata-rata aktivitas guru sebesar 14,50, menunjukan kegiatan belajar mengajar memenuhi syarat berdasarkan pedoman standar keaktivan yaitu keaktivan guru dalam proses belajar mengajar berkategori aktif. Setelah proses pembelajaran dilaksanakan, pada akhir pembelajaran dilakukan evaluasi. Dari hasil evaluasi diperoleh nilai rata-rata 
hasil belajar siswa 74 dengan presentase ketuntasan belajar $90 \%$. Hal ini menunjukan syarat ketuntasan belajar telah tercapai yaitu minimal $85 \%$ siswa yang mendapat nilai $\geq 65$. Setelah dilakukan refleksi ternyata hasil observasi keaktivan siswa dan hasil evaluasi, menunjukan bahwa pada siklus III aktivitas siswa dan hasil evaluasi belajar siswa sudah tercapai sesuai yang diharapkan. Jadi setelah mengalami perbaikan pada siklus III terjadi penigkatan. Dimana pada siklus I skor rata-rata keaktivan siswa 13,65, siklus II skor rata-rata keaktivan siswa 14,30 dan skor rata rata siswa siklus III 19.90 .

Ketercapaian ketuntasan belajar siswa pada siklus III menunjukkan bahwa penerapan model pembelajaran kooperatif tipe Jigsaw menyebabkan suasana kelas lebih hidup dengan partisipasi aktif siswa dalam kegiatan pembelajaran, sehingga pembelajaran menjadi lebih aktif, sikap ini sejalan dengan pendapat J.Burner bahwa belajar adalah suatu perubahan yang mementingkan partisipasi aktif siswa dan mengenal baik adanya perbedaan kemampuan siswa. Keaktifan siswa dalam proses belajar dengan menggunakan model pembelajaran kooperatif tipe Jigsaw menunjukkan bahwa sikap negatif siswa terhadap fisika dengan anggapan bahwa mata pelajaran fisika adalah mata pelajaran yang sulit dan dibenci oleh siswa selama ini ternyata dapat diatasi dengan baik. Karena model pembelajaran kooperatif tipe Jigsaw merupakan konsep pembelajaran yang melibatkan siswa secara langsung untuk lebih aktif dalam proses pembelajaran dalam kelompok yang lebih kecil, serta memberi siswa banyak waktu untuk berpikir, menjawab dan saling membantu satu sama lain (Syarifuddin, 2015).

Pembelajaran kelompok dapat mengaitkan dengan kehidupan sehari-hari siswa dalam konteks pembelajaran kontekstual dan mengembangkan berpikir konstruktivis dari siswa (Wahyuningsih, 2021; Murtalib dkk, 2021; Silviana dkk, 2021). Kemudian penggunaan alat peraga dan penggunaan aplikasi pembelajaran juga dapat diterapkan dalam pembelajaran kooperatif (Khotimah dkk, 2021; Widjathi, 2021).

Dengan menerapkan model pembelajaran kooperatif tipe Jigsaw, mampu meningkatkan aktivitas dan prestasi belajar siswa pada mata pelajaran fisika dan dapat meningkatkan kemampuan siswa dalam mempelajari mata pelajaran fisika yang dianggap sebagai mata pelajaran yang sulit dimengerti. Dari hasil penelitian ini juga diperoleh bahwa semakin meningkatnya aktivitas belajar siswa terhadap mata pelajaran fisika maka semakin meningkat pula prestasi belajar yang dicapai oleh siswa-siswa kelas VIIa SMP Muhammadyah Mataram tahun pelajaran 2020/2021.

\section{KESIMPULAN}

Berdasarkan hasil analisis dan pembahasan dalam penelitian dapat disimpulkan bahwa dengan menerapkan model pembelajaran kooperatif tipe Jigsaw dapat meningkatkan aktivitas dan prestasi belajar siswa kelas VIIA SMPN Muhammadiyah Mataram Tahun Pelajaran 2020/2021 dengan hasil belajar siswa siklus I 55.45, dan ketuntasan klasikalnya $40 \%$, siklus II hasil belajar siswa 66.1, dan ketuntasan klasikalnya $60 \%$, siklus III hasil belajar siswa 74 dan ketuntasan klasikalnya $90 \%$.

Berpedoman pada hasil yang dicapai dalam penelitian ini maka saransaran yang dapat disampaikan adalah diharapkan kepada guru Fisika dan guru SMP Mataram untuk pokok bahasan gerak lurus sebagai salah satu alternatif model pembelajaran kooperatif tipe Jigsaw dalam menigkatkan aktivitas dan prestasi belajar siswa; bagi siswa agar dapat menigkatkan aktivitas dan prestasi belajar siswa pada

@ 2021 JagoMipa (https://bimaberilmu.com/jurnal/index.php/jagomipa) 
mata pelajaran fisika dengan pokok bahasan gerak lurus dengan model pembelajaran kooperatif tipe Jigsaw; bagi mahasiswa yang ingain meneliti lebih lanjut diharapkan mencoba menerapkan pada pokok bahasan yang lain dan lebih sempurna.

\section{DAFTAR PUSTAKA}

Arikunto. (2006. Prosedur Penelitian Suatu Pendekatan Praktek. Jakarta : PT. Rineka Cipta.

Atmarita, A., \& Syarifuddin, S. (2021). Visual Processing Assessment on Children: A Pilot Study. Jurnal Pendidikan dan Pembelajaran Indonesia (JPPI), 1(1), 1-9.

Baeti, N., \& Mikrayanti, M. (2018). Pengaruh Penerapan Model Pembelajaran Kooperatif Teknik Berkirim Salam dan Soal Terhadap Kemampuan Pemahaman Matematis Siswa SMP. Jurnal Ilmiah Mandala Education, 4(2), 189-194.

Djamarah, (2000). Prestasi Belajar dan Kompetensi Guru. Surabaya: Usaha Nasional.

Ermin, E. (2021). Analisis Keterampilan Metakognisi Siswa Pada Mata Pelajaran IPA Biologi di SMP Kota Ternate. Jurnal Pendidikan dan Pembelajaran Indonesia (JPPI), 1(1), 56-60.

Gunawan, G., Murtalib, M., \& Astuti, S. (2020). Perbandingan Prestasi Belajar Siswa Antara Metode Pembelajaran Inquiry Dengan Metode Pembelajaran Ekspositori Pada Materi Pokok Segitiga Siswa SMP. SUPERMAT (Jurnal Pendidikan Matematika), 4(2), 63-73.

Hamalik, Oemar. (2001). Kurikulum dan Pembelajaran. Jakarta. PT Bumi Aksara.

Haryono, Y. (2005). Dasar - Dasar Akuntansi. Yogyakarta: Akademi Akuntansi YKPN

Isjoni. (2009). Pembelajaran Kooperatif Meningkatkan Kecerdasan Komunikasi Antar Peserta Didik. Yogyakarta: PustakaPelajar.

Khotimah, N. K., Ashar, M. U., \& Nurhidayah, N. (2021). Penerapan Metode Diskusi Berbasis E-Learning dengan Penggunaan Aplikasi Edmodo, Zoom Cloud Meeting dan Quizizz untuk Meningkatkan Hasil Belajar Mahasiswa Materi Sistem Pencernaan pada Program Studi Keperawatan UIN Alauddin Makassar. Jurnal Pendidikan dan Pembelajaran Indonesia (JPPI), 1(1), 61-71.

Murtalib, M., Dusalan, D., Marweli, M., \& Rohana, R. (2021). Penerapan Pendekatan Kontekstual pada Materi Pokok Trigonometri untuk Meningkatkan Prestasi Belajar Siswa. Jurnal Pendidikan dan Pembelajaran Indonesia (JPPI), 1(1), 22-29.

Nufus, H. (2021). Penggunaan Lingkungan Sekolah sebagai Laboratorium IPA untuk Meningkatkan Aktivitas dan Hasil Belajar Biologi Siswa Kelas VII MTs. AlIslahussibyan Dopang Gunung Sari. JagoMIPA: Jurnal Pendidikan Matematika dan IPA, 1(1), 44-55.

Nurkencana,Wayan (2000). Evaluasi Hasil Belajar. Surabaya: Usaha Nasional.

Ridwan. (2005). Skala Pengukuran Variabel-Variabel Penelitian. Bandung : Alfabeta 
Rukmini, S., \& Ningsi, F. (2021). Pemberdayaan Lembar Kerja Siswa untuk Meningkatkan Pembelajaran IPA pada Standar Kompetensi Mengidentifikasi Fungsi Organ Tubuh Manusia dan Hewan di Kelas V Semester II SDN 61 Karara Kota Bima Tahun Pelajaran 2019/2020. Jurnal Pendidikan dan Pembelajaran Indonesia (JPPI), 1(1), 72-79.

Silviana, D., Mikrayanti, M., Jauhari, R. S., \& Furqan, M. (2021). Penerapan Realistic Mathematics Education untuk Meningkatkan Aktivitas dan Hasil Belajar Siswa Sekolah Menengah Pertama pada Materi Pokok Fungsi. JagoMIPA: Jurnal Pendidikan Matematika dan IPA, 1(1), 21-35.

Slameto. (2003). Belajar dan Faktor-faktor yang Mempengaruhinya. Jakarta : Rineka Cipta.

Sutarto, S., Pd, M., Syarifuddin, S. P., \& Pd, M. (2013). Desain Pembelajaran Matematika. Yogyakarta: Samudra Biru.

Syarifuddin, (2015). Penerapan Pembelajran Kooperatif tipe Jigsaw dalam Meningkatkan Ketercapaian Kompetensi Matematika Siswa di SMA. Jurnal Pendidikan MIPA 5 (1), 15.

Syarifuddin, S. (2018). Pengaruh Pembelajaran Kooperatif Tipe Jigsaw Dan Tipe Group Investigation (GI) Terhadap Ketercapaian Kompetensi Dan Kemampuan Komunikasi Matematika Siswa Di SMA. Jurnal Ilmiah Mandala Education, 4(1), 163-172.

Syarifuddin, S. (2021). Generalisasi dalam Penalaran Kuantitatif Siswa Melalui Pemecahan Masalah Pecahan. AKSIOMA: Jurnal Program Studi Pendidikan Matematika, 10(2), 659-669.

Syarifuddin, S., Basri, H., Ilham, M., \& Fauziah, A. F. (2021). Efektifitas Pembelajaran Daring Mahasiswa Pendidikan Matematika ditengah Pandemi Covid-19. JagoMIPA: Jurnal Pendidikan Matematika dan IPA, 1(1), 1-8.

Wahidah, W. (2021). Penerapan Model Pembelajaran Kooperatif Tipe Jigsaw untuk Meningkatkan Aktivitas dan Prestasi Belajar Fisika Siswa SMP. JagoMIPA: Jurnal Pendidikan Matematika dan IPA, 1(1), 9-20.

Wahyuningsih, S. (2021). Pembelajaran Berbasis Konstruktivisme untuk Meningkatkan Aktivitas dan Prestasi Belajar Siswa pada Materi Pokok Himpunan. Jurnal Pendidikan dan Pembelajaran Indonesia (JPPI), 1(1), 10-21.

Widjathi, S. S. (2021). Penggunaan alat peraga untuk meningkatkan aktivitas dan prestasi belajar siswa kelas VII MTs. Nw Mataram materi pokok himpunan. Jurnal Pendidikan dan Pembelajaran Indonesia (JPPI), 1(1), 30-48.

Wirahmad, I., Iwansyah, I., \& Dusalan, D. (2020). Upaya Meningkatkan Hasil Belajar Matematika Melalui Penerapan Strategi Pembelajaran Kooperatif Tipe Quick On The Draw. SUPERMAT (Jurnal Pendidikan Matematika), 4(2), 20-31. 